\title{
Squamous cell carcinoma of the esophagus
}

INSERM

\section{Source}

INSERM. (1999). Orphanet: an online rare disease and orphan drug data base. Squamous cell carcinoma of the esophagus. ORPHA:99977

Esophageal squamous cell carcinoma (ESCC) is a type of esophageal carcinoma (EC; see this term) that can affect any part of the esophagus, but is usually located in the upper or middle third. 